\title{
Evaluation of the creditworthiness of extractive industry companies
}

\author{
Ryszard Pukala ${ }^{1}$, Nataliya Vnukova $^{2}$, Tetiana Tokhtamysh ${ }^{3, *}$, Oleksandr Yaholnytskyi ${ }^{3}$, \\ and Kateryna Hranko ${ }^{3}$ \\ ${ }^{1}$ Bronislaw Markiewicz State Higher School of Technology and Economics, 37500, Jaroslaw, \\ Czarnieckiego Str., 16, Poland \\ ${ }^{2}$ Simon Kuznets Kharkiv National University of Economics, 61166, Kharkiv, Science Ave., 9a, \\ Ukraine \\ ${ }^{3}$ Kharkiv National University of Civil Engineering and Architecture, 61002, Kharkiv, Sumska Str., \\ 40, Ukraine
}

\begin{abstract}
The article uses the methodology of assessing the creditworthiness of the National Bank of Ukraine as a borrower for extractive industry companies taking into account the principles and recommendations of the Basel Committee on Banking Supervision. According to the financial statements of the extractive industry companies, variables and coefficients have been counted to calculate the objective function of the integral indicator. The classes of debtors of the surveyed enterprises by years are determined. It has been proved that, with average creditworthiness, the activity of extractive industry companies is risky, but these companies need to attract external funds and financial resources. To measure the risk level of the group of surveyed companies, we used the calculation of asymmetry parameters of the statistical distribution, which showed that the activity of extractive industry companies is risky due to the peculiarities of the industry.
\end{abstract}

\section{Introduction}

The extractive industry plays a significant role in the economy of Ukraine, as it accounts for $15 \%$ of the total output of the industry and has a direct impact on the processing industry, electricity and heat production [1]. Therefore, the urgent question is to find ways to attract additional funds and reserves to stimulate the activities of the analysed companies and the industry as a whole. And to attract foreign investment requires transparent financial reporting of enterprises that will meet international standards and clear and qualitative data on the industry, which aims at the new Law of Ukraine "On Transparency in Extractive Industries" [1].

Poland's mining industry also holds an important place in the country's economy, its share in gross domestic product (GDP) is $2.3 \%$. It employs almost 300,000 people. At the beginning of the XXI century, there is a tendency for a general decrease in the production of mineral resources, except for oil, copper ore, silver and natural gas [2].

\footnotetext{
${ }^{*}$ Corresponding author: tunechka10@gmail.com
} 
In Ukraine, 117 mineral resources have been identified from 120 that consumed by the population, as well as over 20,000 explored deposits. Of these, 8,761 deposits with 95 minerals are of industrial importance: 4,676 deposits of non-metallic minerals; 2233 deposits of combustible minerals; 1705 groundwater, mud and brine deposits; 147 deposits of metallic minerals.

According to the data of the State Scientific and Production Enterprise "State Information Geological Fund of Ukraine", in recent years, coal, iron, manganese, ilmenitezirconium, uranium ores, graphite, kaolin, refractory and refractory clays, flux and cement raw materials, facing and building stone have been produced in significant volumes in Ukraine [3].

The extractive industry is export-oriented, so an increase in investment will promote exports [4].

$48 \%$ of Ukraine's industrial potential and up to $20 \%$ of its human resources are associated with the extraction and use of minerals. In 2018, subsoil use fees accounted for $5 \%$ of the state budget revenues, and 16 subsoil users (in particular, "DTEKPavlohradvuhillya", "Northern GOK", "South GOK", "Central GOK", "Inhulets GOK", "Kryvyi Rih iron ore combine") are among the TOP-100 taxpayers according to the State Fiscal Service [5]. The following minerals occupy the largest share in the dynamics of production: black coal for coking (more than $30 \%$ ); sands siliceous and quartz (more than $30 \%$ ); limestone, flux limestone and other limestone (more than $13 \%$ ).

Among the investments made in the beginning of 2019 in the domestic economy in the amount of $\$ 0,8$ billion, $60 \%$ were directed to the extractive industry, production and processing of glass [6].

As of January 2020, in the structure of the credit portfolio of Ukrainian banking institutions, loans to the wholesale and retail trade account for $36 \%$, as well as to the manufacturing industry $-24 \%$ of the total lending to economic sectors [7]. Extractive industry and quarry mining account for about UAH 7.5 billion in credit, which is about $1 \%$ of the total portfolio, of which: $47 \%$ for crude oil and natural gas; $31 \%$ for extraction of metal ores; $14 \%$ for extraction of other mineral resources and quarry mining; $5 \%$ for provision of support services, etc. [7].

However, as reported by the Council of the National Bank of Ukraine (hereinafter referred to as the NBU), the total credit portfolio of banks in 2019 decreased by $13 \%$ and the largest decrease was observed in lending to the basic and infrastructural sectors of the economy, in particular, the extractive one (-31\%) [8].

In the process of loan granting every bank has a need to assess the creditworthiness of the borrowers, which can significantly reduce the credit risks of non-repayment of the loan, and the borrower is able to obtain a loan on more favorable terms.

Studying the experience of corporate lending in Poland, it is found that from 2010 to 2018 there is a continuous simplification of the procedures for assessing the borrower's creditworthiness. At the same time, as in all European countries, in Poland all banks use credit scoring (a numerical statistical method which consists of a point system of analyzing the qualitative and quantitative indicators of the borrower's creditworthiness and is used by credit institutions both to assess the creditworthiness of borrowers and to identify risks related to consumer crediting), which provides for appropriate decisions on the results of the assessment and determination of the class of the borrower [9].

Most domestic credit assessment techniques [10] do not pay due attention to the assessment features of the sectoral features of the borrower's functioning, as enterprises in different industries are grouped together.

The European integration of the domestic banking system and global trends in the globalization of the economy require some changes in the process of assessing the borrower's creditworthiness, which include, first of all, the implementation of the 
borrower's ratings in the banking practice: internal credit rating, security rating, rating of other credit parameters [10].

The deepening of the investment activity of domestic enterprises requires the attraction of financial resources on a long-term basis. In this regard, the use of traditional approaches to assessing the borrower's creditworthiness is insufficient. Therefore, it is advisable for credit institutions and banking institutions engaged in institutional financing to conduct an additional assessment of the investment attractiveness of economic entities [10].

The purpose of the article is to determine the class of debtors, extractive industry companies, to assess the likelihood of obtaining a loan to finance their activities taking into account the risk level..

\section{Methodology}

Qualitative analysis techniques is based on the aggregate quantitative and qualitative characteristics of the borrower are used in advanced market economies to assess the borrower's creditworthiness. On the basis of a comprehensive assessment, the specific gravity and priority of each criterion are distinguished for the purpose of determining the sum of the scoring points, followed by a table of risk levels and decision gravity making. On the basis of the obtained expert assessments and the specific gravity of the criterion, the aggregate credit risk assessment of each individual borrower is determined and a decision is made about its creditworthiness - potential client, expediency of granting him credit.

NBU Resolution No. 351 as of June 30, 2016 (last revision dated December 28, 2019) approved the Regulation "On determining the size of credit risk by active banking operations by banks of Ukraine" (hereinafter - the Regulation) [11], which was developed in accordance with the principles and recommendations of Basel Committee on Banking Supervision. In accordance with this provision, banks should adjust the calculation of reserves for active operations. The current Regulation accumulates the basic principles for calculating the financial position of Ukrainian banks' borrowers, which are reflected in an improved methodology for assessing the creditworthiness of corporate borrowers. According to this methodology, the bank determines the rating class of the debtor-legal entity depending on the value of the integral indicator taking into account the size of the enterprise (large, medium or small) and type of economic activity. The classification is based on the method of discriminant analysis, which is widely used in the world practice of credit risk assessment.

The calculations of the integral indicator of the financial condition of the borrower-legal entity are carried out according to the multivariate discriminant model according to the formula $[11,12]$ :

$$
\mathrm{Z}=a_{1} \cdot x_{1}+a_{2} \cdot x_{2}+a_{3} \cdot x_{3}+a_{4} \cdot x_{4}+\ldots+a_{n} \cdot x_{n}+a_{0}
$$

where $Z$ is the integral indicator; $x_{1}, x_{2}, \ldots, x_{n}$ are financial ratios determined according to the financial statements of the debtor, the legal entity; $a_{1}, a_{2}, \ldots, a_{\mathrm{n}}$ are parameters, which are determined taking into account the strength and level of financial ratios and are updated annually by the NBU on the basis of financial statements of the debtors-legal entities. The Bank submits to the NBU relevant information on the financial statements of corporate debtors in the form and within the deadlines set by the NBU to update the discriminatory model parameters; $a_{0}$ is a free member of the discriminatory model, the value of which must be updated annually by the NBU.

Depending on the value of the integral indicator, the borrower belongs to a certain range of default probability values that a particular class corresponds to. Financial ratios are determined on the basis of the financial statements for the most recent reporting period. 
Regulation [11] provides for 18 models of calculation of the integral indicator in the context of borrowers belonging to small businesses and large and medium-sized enterprises, as well as differentiation of models into nine groups by types of economic activity. The basic idea of ranking models is to provide sufficient accuracy of credit risk estimates.

The basic list of financial ratios included in the integral valuation model has 11 indicators that characterize all the major items of the borrower's financial position. They include: capital structure, earnings and profitability, liquidity and solvency, turnover. The methodological approach involves different indicators for calculating earnings, which in combination with different bases of calculation provides a small level of correlation of these coefficients. This also applies to turnover and liquidity ratios [13].

The model of calculation of the integral indicator of the debtor-legal entity is selected depending on the type of its economic activity determined according to the graph 2010, 2120 (determined by the type of activity "Financial activity") and based on the debtor's decryption of the 2000 graph data on the income structure of Form No. 2 (2-m, 2-mc) "Statement of financial results", Regulation (standard) of accounting 1 or annual financial statements of debtor-legal entity for the last reporting year, based on the maximum value of the share of income from certain activity (percentage) of total operating income (net income from sales of products (goods and services) and other operating income) [11].

It should be noted that similar methods are used in Poland to evaluate the borrower's creditworthiness and the level of insolvency risk [14, 15].

According to the purpose of the research, extractive industry companies were selected to calculate the borrower's creditworthiness. The target function for the specified industry is as follows [11]:

$$
\begin{gathered}
Z=1.815+ \\
+0.237 \cdot x_{1}+0.408 \cdot x_{10}+0.301 \cdot x_{11}+0.405 \cdot x_{13}+ \\
+0.494 \cdot x_{14}+0.303 \cdot x_{15}+0.234 \cdot x_{17}
\end{gathered}
$$

Data of Form 1 (Balance Sheet) and Form 2 (Statement of Financial Results) for the three reporting annual periods of randomly selected extractive industry companies of Ukraine PJSC "Novoselivsky GOK", PJSC "DTEK Dobropilska CEP", JSC Kremenchuh Career Management "Quartz" and PJSC "Suha balka" were used for the calculations [16, $17,18,19]$. According to the data obtained, the variables of the objective function $\left(x_{i}\right)$ were determined. The obtained variables and coefficients of the equation are presented in the Table 1 .

As can be seen from table 1, all these enterprises in the dynamics have significant differences in the level of indicators, which affects their level of risk of creditworthiness of the borrower. To measure the risk level of the group of analysed extractive industry companies, we used the calculation of asymmetry parameters of the statistical distribution according to the formula [20]:

$$
A_{s}=\frac{\frac{1}{n} \cdot \sum_{t=1}^{n}\left(x_{i}-\frac{1}{n} \sum_{t=1}^{n} x_{i}\right)^{3}}{\left(\sqrt{\frac{n}{n-1} \sum_{t=1}^{n}\left(x_{i}-\frac{1}{n} \sum_{t=1}^{n} x_{i}\right)^{2}}\right)^{3}} .
$$

where $n$ is the sample volume.

The economic meaning of asymmetry calculation $\left(A_{s}\right)$ is as follows: if $A_{s}<0$, the activities of the enterprises can be considered risky saturated; if $A_{s}>0$, the activities of the 
enterprises tend to exit from risk saturation; if $A_{s}=0$, the activities of the enterprises are stable.

Table 1. Variables $x_{i}$ and equation coefficients for calculating the objective function $\mathrm{Z}$.

\begin{tabular}{|c|c|c|c|c|c|c|c|c|}
\hline \multirow{4}{*}{ Enterprises } & \multicolumn{8}{|c|}{ Equation coefficients } \\
\hline & 1.815 & 0.237 & 0.408 & 0.301 & 0.405 & 0.494 & 0.303 & 0.234 \\
\hline & \multicolumn{8}{|c|}{ Variables } \\
\hline & const & $x_{1}$ & $x_{10}$ & $x_{11}$ & $x_{13}$ & $x_{14}$ & $x_{15}$ & $x_{17}$ \\
\hline \multicolumn{9}{|c|}{ Reporting annual period 1} \\
\hline $\begin{array}{c}\text { PJSC } \\
\text { "Novoselivsky } \\
\text { GOK" }\end{array}$ & 1 & 1.379 & 0.572 & 1.369 & 0.248 & 0.669 & 1.261 & - \\
\hline $\begin{array}{c}\text { PJSC "DTEK } \\
\text { Dobropilska } \\
\text { CEP" }\end{array}$ & 1 & 1.04 & 0.572 & 1.105 & 0.248 & 0.087 & 1.261 & 1.307 \\
\hline $\begin{array}{c}\text { JSC } \\
\text { "Kremenchuh } \\
\text { Career } \\
\text { Management } \\
\text { "Quartz" }\end{array}$ & 1 & -0.543 & -0.543 & -0.055 & 0.054 & 0.682 & -1.19 & - \\
\hline $\begin{array}{l}\text { PJSC "Suha } \\
\text { balka" }\end{array}$ & 1 & 0.723 & 0.572 & 1.105 & -1.19 & 0.087 & -1.19 & - \\
\hline \multicolumn{9}{|c|}{ Reporting annual period 2} \\
\hline $\begin{array}{c}\text { PJSC } \\
\text { "Novoselivsky } \\
\text { GOK" }\end{array}$ & 1 & 1.379 & 0.572 & 1.369 & 0.248 & 0.087 & - & - \\
\hline $\begin{array}{c}\text { PJSC "DTEK } \\
\text { Dobropilska } \\
\text { CEP" } \\
\end{array}$ & 1 & 1.04 & 0.572 & 1.105 & 0.248 & 0.087 & 1.261 & 1.307 \\
\hline $\begin{array}{c}\text { JSC } \\
\text { "Kremenchuh } \\
\text { Career } \\
\text { Management } \\
\text { "Quartz" }\end{array}$ & 1 & -1.749 & -1.282 & $-0,722$ & -0.24 & 0.682 & -1.46 & -1.773 \\
\hline $\begin{array}{l}\text { PJSC "Suha } \\
\text { balka" }\end{array}$ & 1 & 0.723 & -0.543 & 0.644 & -1.19 & 0.669 & -1.19 & - \\
\hline \multicolumn{9}{|c|}{ Reporting annual period 3} \\
\hline $\begin{array}{c}\text { PJSC } \\
\text { "Novoselivsky } \\
\text { GOK" }\end{array}$ & 1 & 1.379 & 0.572 & 1.369 & 0.248 & 0.669 & - & - \\
\hline $\begin{array}{c}\text { PJSC "DTEK } \\
\text { Dobropilska } \\
\text { CEP" }\end{array}$ & 1 & 1.04 & 0.572 & 1.105 & 0.248 & 0.087 & 1.261 & 1.307 \\
\hline $\begin{array}{c}\text { JSC } \\
\text { "Kremenchuh } \\
\text { Career } \\
\text { Management } \\
\text { "Quartz" }\end{array}$ & 1 & -1.749 & -1.282 & -0.055 & -0.24 & 0.682 & -1.19 & -0.199 \\
\hline $\begin{array}{c}\text { PJSC "Suha } \\
\text { balka" }\end{array}$ & 1 & 1.04 & 0.572 & 0.644 & -0.24 & 0.952 & 0.83 & - \\
\hline
\end{tabular}




\section{Results and their research}

According to the methodology of assessing the creditworthiness of the NBU as the borrower for extractive industry companies taking into account principles and recommendations of the Basel Committee on Banking Supervision [11] (Table 2), a target function for each enterprise in the context of annual reporting periods is found.

Table 2. Determination of the class of debtor-extractive industry company by integral indicator.

\begin{tabular}{|c|c|c|c|c|c|c|c|c|c|}
\hline \multicolumn{10}{|c|}{ The ranges of values of the integral indicator by classes } \\
\hline Value & class & class & class & class & class & class & class & class & class \\
& 1 & 2 & 3 & 4 & 5 & 6 & 7 & 8 & 9 \\
\hline $\begin{array}{c}\text { Greater } \\
\text { than or } \\
\text { equal to }\end{array}$ & +3.55 & +2.90 & +2.25 & +1.60 & +0.95 & +0.31 & -0.34 & -0.99 & - \\
\hline $\begin{array}{c}\text { Less } \\
\text { than }\end{array}$ & - & +3.55 & +2.90 & +2.25 & +1.60 & +0.95 & +0.31 & -0.34 & -0.99 \\
\hline
\end{tabular}

The results of determining the class of debtor-legal entity by integral indicator are given in Table. 3.

Table 3. The results of determining the class of debtor-legal entity by the integrated indicator of selected extractive industry companies.

\begin{tabular}{|c|c|c|c|}
\hline Enterprises & $\begin{array}{c}\text { Reporting annual } \\
\text { period }\end{array}$ & Target function & Borrower class \\
\hline \multirow{3}{*}{ PJSC "Novoselivsky GOK" } & 1 & 3.60 & 1 \\
\cline { 2 - 4 } & 2 & 2.93 & 2 \\
\cline { 2 - 4 } & 3 & 3.22 & 2 \\
\hline \multirow{2}{*}{ PJSC "DTEK Dobropilska } & 1 & 3.46 & 2 \\
\cline { 2 - 4 } CEP" & 2 & 3.46 & 2 \\
\cline { 2 - 4 } & 3 & 3.46 & 5 \\
\hline \multirow{2}{*}{$\begin{array}{c}\text { JSC "Kremenchuh Career } \\
\text { Management "Quartz" }\end{array}$} & 1 & 1.45 & 7 \\
\cline { 2 - 4 } & 2 & 0.04 & 4 \\
\hline \multirow{3}{*}{ PJSC "Suha balka" } & 3 & 0.69 & 5 \\
\cline { 2 - 4 } & 2 & 1.75 & 2 \\
\hline
\end{tabular}

As can be seen from the Table 3, half of the selected borrowers-extractive industry companies have been identified as 2 nd class, only in one period one company had the best 1 st class, in other periods the class of the borrower is significantly lower (4-7), which is not acceptable for crediting according to the established risk. The calculated integral indicator only of PJSC "Novoselivsky GOK" in the first reporting annual period showed that the company belongs to 1st class of borrowers. An analysis of its financial statements [18] showed that current liabilities and collateral were less than $7 \%$. In the second and third reporting periods, the company belonged to 2 nd class of borrowers at the expense of a significant increase in current accounts payable for goods, works, services and other current liabilities. This situation was observed during all the analyzed periods at PJSC "DTEK Dobropilska CEP". During the period under review, the equity of the company was approximately $76 \%$. It doubled due to a significant increase in retained earnings. In the liability structure, long-term liabilities and collateral are insignificant (less than $5 \%$ ). The main items of short-term accounts payable are current accounts payable for goods, works, 
services and advances received [16]. Both enterprises have a sufficient class of borrower for the studied period to obtain lending, and now they operate at their own expense.

According to the results of the calculations, JSC "Kremenchuh Career Management "Quartz" belongs to the 5th class of the borrowers in the first reporting period, to the 7th class in the second and the 6th class in the third reporting period. This situation was at the enterprise, as its retained loss increased more than 3 times (according to the balance sheet asset [17] during the reporting periods, from UAH 10 million to UAH 33.2 million). The activity of the company is directly related to the attraction of long-term and short-term funds.

PJSC "Suha balka" in the first and second reporting periods belonged to the 4th and 5th classes of the borrower, respectively. This is due to a significant amount of current accounts payable on advances received, which accounted for almost $75 \%$ of the balance sheet liability (UAH 2,27 billion), as confirmed by the financial statements of the company [19]. In the third reporting period, the company settled on its obligations on advances received, and therefore the class of the borrower improved significantly and it was reffered to the 2nd class. Long-term debt is represented only by other long-term liabilities of about $17 \%$ [19].

Thus, the overall indicators of creditworthiness of PJSC "Novoselivsky GOK" according to the credit rating of the debtor of the rating agencies "Standard \& Poor's" and "Fitch Ratings" corresponds to the rating from AAA to AA-, which indicates the high ability of the company to meet its financial obligations. The overall creditworthiness of PJSC "DTEK Dobropilska CEP" corresponds to the rating from AA to AA- according to the national credit rating scale. This means that the company has a high level of solvability. JSC "Kremenchuh Career Management "Quartz" is exposed to credit risk in the conditions of unfavorable business, financial and economic conditions. There is little ability to fulfill financial obligations. PJSC "Suha balka" has changed its rating of the borrower from BB to AA (from a slight tendency to credit risk in the short term to a high ability to fulfill its financial obligations).

The asymmetry index is determined by the formula (3) and using the data in Table 3 , the calculations showed that the asymmetry coefficient for the studies period was at the level (-0.74). This means that the activities of the group of companies selected for research are risky.

In Ukraine, on September 18, 2018, the Law "On Provision of Transparency in Extractive Industries" was adopted [12], which will allow to manage the oil, gas and mineral resources more effectively and will open the opportunity for Ukrainian companies to attract European investments. The state and investors will receive reliable data on the state of the extractive industry companies from the payment report, audit reports, which will disclose information about the owners of the company, the number of employees, taxes and other flows of funds.

Under these conditions, it will be easier to compare extractive industry companies, to find out what their differences are, why one is profitable and the other is unprofitable, and in which of the business segments there is potential for efficiency gains. The new law promotes transparency and, in addition, associations between Ukraine and the EU. The next goal is the current balance of the environment, society, economy. The ultimate goal is the development of a long-term strategy for the use of subsoil and the entry of Ukraine into the path of sustainable development [1].

The lack of sufficient information support about the current financial position of borrowers and the lack of critical appraisal skills of financial reporting is a challenge in banks' credit assessment activities. There are cases of non-transparency and falsification by the borrowers of official financial statements either by overestimating the revenue generated or by reducing the costs incurred. It is necessary to search for modern methods of analyzing the activity of the borrower in the presence of uncertain information to ensure the 
objectivity of the results obtained, if the source information is not sufficiently comprehensive or unreliable. The calculation showed the need to look for additional indicators for assessing credit risk, such as the one identified by the group of enterprises.

As reported by the NBU, about $67 \%$ of respondents do not attract foreign investments to finance their activities [21]. At the same time, $71 \%$ of respondents describ their financial status as satisfactory. At the same time, $38 \%$ of the surveyed respondents in the extractive industry emphasized the need to attract loans in the short term. The key factors that holding back extractive industry companies from attrackting loans from banks are: too high interest rates (52\% of respondents), complicated paperwork $(26.1 \%)$ and excessive mortgage requirements $(26.1 \%)$. Thus, a decrease in the NBU discount rate in 2020 will help to revive credit activity.

Improving the methodology for assessing the creditworthiness of borrowers, introducing a new approach to assessing credit risk by banks testifies to the NBU's actions in reforming the system of regulating banks' activities in accordance with international standards. Meanwhile, in order to reduce the credit risk, more in-depth studies are needed on a separate type of economic activity of extractive industry companies only. Reducing the risk of borrowing operations can be achieved on the basis of a comprehensive study of the creditworthiness of the borrower, that is, it is necessary to combine in a methodical approach of determining the creditworthiness of borrowers not only the financial condition evalution, but also the qualitative indicators of financial and economic activity of the company.

\section{Conclusions}

The low level of credit granting in Ukraine to extractive industry companies is explained by their risk-intensive, which is determined both by assessing the creditworthiness of a group of enterprises and by measuring the level of risk of their activity. Therefore, banks are very cautious about creditgranting to extractive industry companies, which may be due to the high credit risk, since in this type of economic activity there are insufficient number of solvent enterprises. The low credit share to the extractive industry in the economy may also be related to the financial statements of enterprises with past due loans of previous periods. Meanwhile, the fact that the extractive industry has a slight reduction in overdue loans (about 2.5 percentage point), it creates positive prospects, which can be confirmed by the fact that in half of the reporting periods the borrower class of the studied enterprises was 2 , which is acceptable for credit.

Limited lending of the extractive industry may also be connected with the high capital intensity of the industry, which is associated with constant capital construction, the creation of new value fixed assets, exploration and preparation of new fields. Meanwhile, credit funds are sent to debt restructuring, not creating a basis for industrial development.

Strategic objectives to revitalize the activity of extractive industry companies by attracting the necessary amount of funds will create a significant multiplier effect in the country's economy and will be the key to creating working places in other sectors of the economy.

\section{References}

1. Budnik, M. Enerhetyka Ukrainy 2018. Retrieved from: https://businessviews.com.ua/ ru/get_file/id/the-infographics-report-energy-of-ukraine-2018.pdf

2. Promyslovist Polshchi. Retrieved from: http://www.geograf.com.ua/poland/693-polandindustry 
3. Derzhavne naukovo-vyrobnyche pidpryiemstvo "Derzhavnyi informatsiinyi heolohichnyi fond Ukrainy". Stan zapasiv rodovyshch korysnykh kopalyn Ukrainy. Retrieved from: http://geoinf.kiev.ua/stan-zapasiv-rodovyshch-korysnykh-kopalynukrayiny/

4. Vnukova, N., Kovalchuk, V., Antsyferova, O. Assessment of investment impact on the volumes of export Economic Annals-XXI 2014/01/01. 48-51

5. Goloborodko, T.V., Shmagajlo, S.S. (2018). Doslidzhennia podatkovykh nadkhodzhen: derzhava, haluzi, rehiony. Efektyvna ekonomika. Retrieved from: http://www.economy.nayka.com.ua/pdf/6_2018/68.pdf

6. Kuziutkin, L. Kolo interesiv: Top-3 napriamky investytsii v Ukrainu. Retrieved from: https://yur-gazeta.com/dumka-eksperta/kolo-interesiv-top3-napryamki-investiciy-vukrayinu.html

7. Hroshovo-kredytna statystyka Natsionalnoho banku Ukrainy. Kredyty, nadani depozytnymy korporatsiiamy (krim Natsionalnoho banku Ukrainy). (2020). Retrived from_https://bank.gov.ua/files/3.3-Loans.xlsx

8. Furman, V. Chy stane 2020 rokom kredytuvannia ekonomiky. Retrieved from: https://www.epravda.com.ua/columns/2020/03/10/657884/

9. Slaviuk, R.A. (2018). Evaluation the creditworthiness of borrowers: experience of Poland. Infrastuktura rynku, (19), 497-505

10. Yepifanov, A.O., Dekhtiar, N.A., Melnyk, T.M., Shkolnyk, I.O. ta in. (2007). Otsinka kredytospromozhnosti ta investytsiinoi pryvablyvosti subiektiv hospodariuvannia: Monohrafiia. Sumy: UABS NBU. Retrived from_https://essuir.sumdu.edu.ua/bitstreamdownload/123456789/50498/7/Yepifanov_Otsinka_kredytospromozhnosti.pdf;jsessioni $\mathrm{d}=13 \mathrm{CD} 8 \mathrm{C} 15 \mathrm{~F} 92 \mathrm{BCFEF00BDAE9C2A465503}$

11. Postanova No 351. (2016). Polozhennia pro vyznachennia bankamy Ukrainy rozmiru kredytnoho ryzyku za aktyvnymy bankivskymy operatsiiamy. Kyiv: Natsionalnyi bank Ukrainy. Retrieved from: https://zakon.rada.gov.ua/laws/show/v0351500-16/

12. Zakon Ukrainy №2545-VIII. (2018). Pro zabezpechennia prozorosti u vydobuvnykh haluziakh. Retrieved from: https://zakon.rada.gov.ua/laws/show/2545-19

13. Dzhedzhula, V.V, Czvyk, O.G. (2016). Modern methodological approaches to assessing the creditworthiness of the enterprise. Ekonomika i suspilstvo. 7. Retrieved from: http://economyandsociety.in.ua/journal/7_ukr/49.pdf

14. A. Feruś, Finanse, Rynki Finansowe, Ubezpieczenia, 1 (2016)

15. M. Pawłowski, Polityki Europejskie, Finance i Marketing, 19(68) (2018)

16. Richna finansova zvitnist emitenta Publichnoho aktsionernoho tovarystva PJSC "DTEK Dobropilska CEP". Retrieved from: https://smida.gov.ua/db/participant/00176472.

17. Richna finansova zvitnist emitenta Publichnoho aktsionernoho tovarystva "Kremenchutske karieroupravlinnia "Kvarts". Retrieved from: https://smida.gov.ua/ db/participant/35328439

18. Richna finansova zvitnist emitenta Pryvatnoho aktsionernoho tovarystva "NOVOSELIVSKYI hirnycho-zbahachuvalnyi kombinat". Retrieved from: https://smida.gov.ua/db/participant/30773938

19. Richna finansova zvitnist emitenta Pryvatnoho aktsionernoho tovarystva "SUKHA BALKA". Retrieved from: https://smida.gov.ua/db/participant/00191329

20. Smolyak, V.A. (2005). Economic risk assessment of industrial enterprises: Avtoref. dys. na zdobuttya nauk. stupenya kand. ekon. nauk. Kharkiv. 23

21. Natsionalnyi bank Ukrainy. Dilovi ochikuvannia pidpryiemstv Ukrainy. (2019). Retrieved from: https://bank.gov.ua/admin_uploads/article/BOS_2019-Q2.pdf?v=4 